\title{
MICROBIOLOGICAL BASIS FOR PERIODONTAL THERAPY
}

\author{
BASES MICROBIOLÓGICAS PARA A TERAPIA PERIODONTAL
}

\author{
Magda FERES ${ }^{1}$, Sheila Cavalca CORTELLI ${ }^{2}$, Luciene Cristina FIGUEIREDO², Anne D. HAFFAJEE ${ }^{3}$, Sigmund S. SOCRANSKY ${ }^{3}$
}

1- DDS, MSc, PhD, Assistant Professor and Chair, Dental Research Division, Department of Periodontology, Guarulhos University-SP, Brasil.

2- Assistant Professor, Dental Research Division, Department of Periodontology, Guarulhos University-SP, Brasil.

3- Senior Member of Staff, Department of Periodontology, The Forsyth Institute-Boston MA, USA.

Corresponding address: Magda Feres - Universidade Guarulhos. CEPPE - Centro de Pós-Graduação, Pesquisa e Extensão.

Praça Tereza Cristina, 1 - Centro. Guarulhos, SP. - 07023-070 - Phone: (11) 6464-1684 - Fax: (11) 6464-1758 - Email: mferes@ung.br

Received: November 13, 2003 - Returned for modification: April 04, 2004 - Accepted: September 23, 2004

\begin{abstract}
Thes

Le search for the etiologic agents of periodontal diseases started in the Golden Era of medical bacteriology, when the etiologic agents of many bacterial infections were isolated and characterized. After the initial enthusiasm in establishing the infectious nature and the true agents of periodontal diseases, this concept was virtually ignored for the next four decades. Until the early 1970s treatment regimens based on the non-specific plaque hypothesis were directed towards a non-specific reduction in plaque amount. Later, the specific plaque hypothesis established the role of some microorganisms such as $A$. actinomycetemcomitans, $P$. gingivalis, T. forsythensis, T. denticola, P. intermedia and F. nucleatum in different forms of periodontal diseases. It was recently suggested that these suspected periodontal pathogens seem to not act alone and interactions between species, especially the balance between pathogenic and beneficial species affect both progression of disease and response of tissues to periodontal therapy. Nowadays it is well established that one of the goals of therapy is to control such periodontal pathogens. Among the most commonly used therapies to treat periodontal infections are scaling and root planing (SRP), supragingival plaque control and periodontal surgeries. Many studies confirmed the reduction of "red complex" species by SRP, and apically repositioned flap can lead to an additional beneficial effect in the subgingival microbiota by decreasing levels of "red" and "orange complexes" species. Furthermore, the level of plaque control maintained by the patients has been considered a crucial step in preventing recurrence of destructive periodontitis.

Uniterms: Bacteria; Periodontitis; Toothbrushing; Dental scaling; Surgical procedures.
\end{abstract}

\section{RESUMO}

A

busca pelos agentes etiológicos das doenças periodontais iniciou na Época de Ouro da bacteriologia médica, quando os agentes de diversas infecções foram identificados. Após o entusiasmo inicial em estabelecer a natureza infecciosa da doença periodontal, este conceito foi ignorado por quatro décadas. Até o início dos anos 70, terapias baseadas na hipótese da placa não-específica focavam a redução da quantidade de placa. Posteriormente, a hipótese da placa específica determinou o papel de alguns microorganismos como A.actinomycetemcomitams, P.gingivalis, T.forsythensis, T.denticola, P.intermedia e F.nucleatum nas diferentes formas de doença periodontal. Recentemente, foi sugerido que estes patógenos periodontais não atuam isoladamente e interações entre espécies, como o equilíbrio entre bactérias patogênicas e benéficas afetam a progressão da doença e a resposta tecidual à terapia periodontal. Atualmente está bem estabelecido que um dos objetivos da terapia é o controle destes patógenos. Dentre as terapias mais freqüentemente utilizadas no tratamento da periodontite estão raspagem e alisamento radicular (RAR), controle da placa supragengival e cirurgias periodontais. Muitos estudos confirmaram a redução de espécies do "complexo vermelho" pela RAR, e mostraram que o retalho reposicionado apicalmente pode levar a um efeito benéfico adicional na microbiota subgengival pela diminuição nos níveis de espécies dos “complexos vermelho" e "laranja”. Além disso, o controle de placa mantido pelos indivíduos é considerado determinante para a prevenção da recorrência de doença periodontal destrutiva.

Unitermos: Bactérias; Periodontite; Escovação dentária; Raspagem dentária; Procedimentos cirúrgicos. 


\section{BACTERIAL ETIOLOGY OF PERIODONTAL DISEASES}

\section{The Early Years}

The search for the etiologic agents of periodontal diseases started in the Golden Era of medical bacteriology (1880 to 1920), when the etiologic agents of many bacterial infections were isolated and characterized. Groups of investigators applied the microbiological techniques available at that time to study the oral microbiota ${ }^{1,2,3}$. As a result numerous papers published during this period suggested specific etiological agents of periodontal diseases, including spirochetes ${ }^{2}$, fusiforms ${ }^{3}$ and streptococci ${ }^{1}$.

After the initial enthusiasm in establishing the infectious nature and agents of periodontal diseases, this concept was virtually ignored for the next four decades. From the mid1920 s to the early 1960s a series of different factors were considered to cause or to be related with the nature of periodontal lesions ${ }^{4}$. Among them were the concept of passive eruption developed by Gottlieb ${ }^{5}$, local irritation of the periodontium ${ }^{6}$, constitutional defects ${ }^{7}$ and functional occlusal disturbances ${ }^{8}$. Bacteria were thought to be merely secondary invaders in this process ${ }^{9}$.

Treatment of patients based on the notion of constitutional defects or trauma from occlusion was not effective in controlling periodontal diseases. The absence of a single paradigm for the research into the cause of periodontitis, and the failure of preventive and therapeutic actions to yield predictable results generated profound professional insecurity ${ }^{10}$. Animal studies carried out in the early 1960s brought the microbial etiology of periodontal diseases into focus again ${ }^{11,12,13,14,15}$. Keyes and Jordan ${ }^{14}$ demonstrated that periodontal diseases could be transmitted in hamsters from animals with disease to animals without disease by caging them together. Jordan and Keyes ${ }^{13}$ also showed that the species now known as Actinomyces viscosus was the only species capable of causing destructive periodontitis in hamsters without disease. Gibbons and Socransky ${ }^{12}$ inoculated germ-free mice with organisms from human periodontal pockets and observed an increase in the severity of bone loss in these animals. In addition, strains of streptococci (Streptococcus mutans) ${ }^{11}$, as well as Grampositive rods (particularly Actinomyces naeslundii) ${ }^{16}$ isolated from the human oral cavity were shown to induce plaque formation, caries and alveolar bone loss in gnotobiotic as well as conventional rats.

At the same time, epidemiological ${ }^{17}$, and cross-sectional ${ }^{18}$ studies demonstrated a close relation between oral hygiene and periodontal pathology and rekindled interest in the importance of bacterial plaque in the etiology of periodontal diseases. A study performed by Schei and co-workers ${ }^{17}$ in a Norwegian population showed that individuals with abundant plaque exhibited increased amounts of alveolar bone loss compared to subjects with less dental plaque. The classic study of "experimental gingivitis" by Löe and co-workers ${ }^{18}$ demonstrated that plaque led to gingivitis confirming the relationship between plaque accumulation and gingival inflammation. However, at that time, it was thought that periodontal diseases resulted from an overall growth of plaque and that virtually any organism present in the subgingival plaque could contribute to tissue destruction. This concept became known as the "nonspecific plaque hypothesis”.

Until the early 1970s treatment regimens based on the non-specific plaque hypothesis were directed towards a nonspecific reduction in plaque amount. It was thought that the composition of plaque was similar from patient to patient and from site to site. However, observations from newer epidemiological surveys indicated that only certain individuals or sites exhibited attachment loss and that some populations in Sri Lanka ${ }^{19}$ and Kenya ${ }^{20}$ had a large amount of calculus and plaque with minimal or no periodontal attachment loss.

These data contradicted the principles of the non-specific plaque hypothesis. If plaque composition was consistent from individual to individual, why did some subjects who accumulated much plaque fail, even after many years, to develop destruction of the supporting structures? On the other hand, why did some individuals with little detectable plaque develop rapid periodontal destruction? Further, why did some sites in the oral cavity of the same individual lose attachment while others did not? ${ }^{4}$

\section{Re-introduction of Bacterial Specificity}

Partial answers to these questions came from more recent studies on the microbiology of periodontal diseases. Listgarten, et al..$^{21}$ studied the structure of the microbiota on extracted natural teeth from patients with a diagnosis of health, gingivitis or periodontitis and observed many differences in terms of plaque composition. The plaque associated with the periodontally healthy tooth was composed of coccoid mainly Gram-positive species. A marked increase in the periodontal mass, as well as a relative increase in the proportion of Gram-negative bacteria, motile rods and filaments characterized the gingivitis-associated microbiota. In samples of teeth from adult periodontitis subjects, an abundant, complex microbiota was observed in the periodontal pockets, presenting a predominantly Gramnegative bacterial population, with a large proportion of spirochetes. Other cultural and microscopic study confirmed the morphological differences in the composition of the subgingival microbiota in subjects with different clinical status $^{22}$

Besides these morphological studies, the recognition that certain forms of periodontal disease such as necrotizing ulcerative gingivitis (NUG) and localized juvenile periodontitis (LJP) were distinct clinical entities, probably associated with specific microorganisms, led to the reintroduction of specificity in the bacterial etiology of periodontal diseases, the "specific plaque hypothesis". Listgarten in the $1960 \mathrm{~s}^{23}$ had shown that medium sized spirochetes were present in practically pure culture in the lesions of NUG within the connective tissue and the adjacent 
epithelium. The importance of this observation was not realized at that time. The introduction of improved cultural methods, such as continuous anaerobiosis techniques, new culture media, better sampling and dispersion of plaque, facilitated the characterization and identification of new pathogens and later the evaluation of different therapies.

\section{Localized Juvenile Periodontitis}

In 1976, Slots ${ }^{24}$ studied the predominant cultivable microorganisms in juvenile periodontitis and demonstrated that the microbial composition of subgingival plaque taken from diseased sites differed substantially from the samples taken from healthy sites. He found that the microbiota from the control sites consisted primarily of streptococci, Gramnegative and Gram-positive rods. In contrast, the test pockets had a relatively stable microbiota, dominated by Gram-negative anaerobic rods, but facultative cocci and rods were also present; one facultative (capnophilic) Gramnegative rod species was later classified as Actinobacillus actinomycetemcomitans. Other investigations confirmed Slots' finding that this organism was elevated in active sites when compared with inactive sites in patients with $\mathrm{LJP}^{25,26,27}$. In addition, many other studies showed an increase in the frequency of detection and higher numbers of this organism in lesions of LJP when compared with plaque samples from other clinical conditions including periodontitis, gingivitis and health ${ }^{28,29,30,31}$. Furthermore LJP patients often demonstrated markedly elevated levels of local and systemic antibodies to A. actinomycetemcomitans ${ }^{32,33,34,35}$. This organism was also shown to invade human gingival epithelial cells in vitro ${ }^{36}$. It was also shown that successful treatment of LJP patients was associated with the elimination or reduction of this species, whereas failure was related to persistence of high levels of this organism ${ }^{25,37}$. Collectively, the data suggested that A. actinomycetemcomitans is a probable pathogen of LJP.

\section{Chronic Periodontitis}

The recognition that subjects with LJP could be treated successfully with local debridement and systemic antibiotics provided impetus to studies attempting to relate specific microorganisms to the etiology of different periodontal diseases. Another intensively studied probable periodontal pathogen is Porphyromonas gingivalis. Early interest in $P$. gingivalis and other black-pigmented Bacteroides arose primarily because of their essential role in experimental mixed infections ${ }^{15}$ and their production of a large number of virulence factors ${ }^{38,39,40}$. The association of $P$. gingivalis with disease came from studies that demonstrated that the species was uncommon in health and gingivitis but more frequently detected in destructive forms of disease ${ }^{41,42,43,44}$. P. gingivalis has been shown to be reduced in successfully treated sites but commonly encountered in samples from sites that exhibited recurrence of post-therapy disease $\mathrm{e}^{45,46}$. Studies of ligature-induced periodontitis in animals indicated a very strong relation between $P$. gingivalis-like organisms and disease ${ }^{47}$. Like A. actinomycetemcomitans, P. gingivalis has been shown to be able to invade human gingival epithelial cells in vitro ${ }^{48}$.

\section{Studies Employing Specific Antisera or DNA Probes}

The development of new techniques using polyclonal or monoclonal antibodies and DNA probes was very important in more precisely discriminating subgingival species, especially those that were difficult to cultivate by traditional cultural methods, such as Bacteroides forsythus and spirochetes.

Initially, $B$. forsythus (recently reclassified as Tannerella forsythensis by Sakamoto, et al. ${ }^{49}$, 2002) was thought to be a relatively uncommon subgingival species. However, immunological studies using monoclonal antibodies and fluorescent-labeled polyclonal antisera suggested that this species was more common than previously found in cultural studies and that its levels were strongly related to increased periodontal pocket depth ${ }^{50,51,52,53,54}$. Haffajee, et al. ${ }^{55}$, using the checkerboard DNA-DNA hybridization technique, found very high levels of this organism in subgingival plaque samples of 57 patients with adult periodontitis. In addition, the authors observed that $T$. forsythensis was infrequently detected in epithelial cell samples from healthy subjects. Finally, serum antibody to T. forsythensis has been found to be elevated in many periodontitis patients ${ }^{56}$.

The spirochetes are another group of organisms implicated in the etiology of periodontal diseases. The difficulty in growing and distinguishing individual species has been the major difficulty in defining species of spirochetes as periodontal pathogens. Clearly, a spirochete has been implicated as the likely etiological agent in NUG by its presence in large numbers in tissue biopsies from affected sites ${ }^{23}$. However, this species remains uncultivated. In recent years, specific species of spirochetes have been related to periodontal breakdown. Treponema denticola was found to be more common in periodontally diseased than in healthy sites and more frequent in subgingival than in supragingival plaque ${ }^{57,58,59}$. T. denticola was shown to be decreased in successfully treated periodontal sites but not changed or increased in nonresponding sites ${ }^{60,61}$. More recently, Haffajee, et al. ${ }^{55}$ found that almost $35 \%$ of the subgingival sites in adult periodontitis patients were colonized with strains of T. denticola. Socransky and coworkers $^{62}$ observed that together with $T$. forsythensis and $P$. gingivalis, $T$. denticola strikingly related to clinical measures of periodontal disease, particularly increased pocket depth and bleeding on probing ${ }^{43}$. Additionally, T. denticolareactive IgA was found to be elevated in aggressive periodontitis patients ${ }^{35}$. These studies suggested that certain species of spirochetes were important in the pathogenesis of specific forms of periodontitis. However, the studies evaluated only the limited number of spirochetes species that have been successfully cultivated, suggesting the possibility that other spirochetes might be involved ${ }^{59}$. 


\section{Other Possible Pathogens of Periodontitis}

Other organisms have been suggested to play a role in disease, including Prevotella intermedia ${ }^{34,52,61,63,64}$, Fusobacterium nucleatum ${ }^{34,52,65}$, Campylobacter rectus $^{27,34,66,67}$, Eikenella corrodens ${ }^{34,67}$, Peptostreptococcus micros $^{51,65}$, Streptococcus intermedius ${ }^{65,68}$ and Capnocytophaga $s p p^{64}$. However the data on the role of these organisms in different forms of periodontal diseases $^{69,70,71}$ and in specific populations ${ }^{72}$ are less developed than for the species described above.

\section{Microbial Interactions and Complexes}

It is important to emphasize that these "possible periodontal pathogens" do not act alone ${ }^{59}$. No subgingival site harbors pure cultures of a single bacterial species. Thus, interactions between species are critical in affecting the outcome of disease or no disease ${ }^{72,73}$. Some authors ${ }^{74,75}$ suggested the importance of a balance between "beneficial" and "pathogenic" species. The presence and levels of these host-compatible or host-beneficial species were critical both to the initiation of disease and to the control of post-therapy disease $\mathrm{e}^{74,76}$. The species considered "beneficial" included Veillonella parvula, Actinomyces sp., or the combination of Streptococcus sanguis II (Streptococcus oralis), Streptococcus mitis, V. parvula and S. intermedius. Clusters of these microorganisms were observed in samples from sites that exhibited less active disease and responded more favorably to therapy ${ }^{74}$.

Socransky, et al. ${ }^{62}$ described 5 major microbial complexes observed in subgingival plaque samples from a wide range of subjects ( 160 periodontitis and 25 periodontally healthy subjects). The presence and levels of 40 subgingival species were determined in 13,261 subgingival plaque samples using DNA probes. Cluster analysis and community ordination techniques were used to examine the relationships between bacterial species. One complex, called the "red complex", consisted of 3 tightly related species: T. forsythensis, $P$. gingivalis and T. denticola. As mentioned before, this complex strongly related to pocket depth and bleeding on probing. Another complex ("the orange complex") included F. nucleatum/periodonticum subspecies, P. intermedia, Prevotella nigrescens, $P$. micros, C. rectus, Campylobacter gracilis, Campylobacter showae, Eubacterium nodatum and Streptococcus constellatus, and seemed to precede colonization by species of the "red complex". The so-called "yellow complex" consisted of 6 Streptococcus species: Streptococcus sp., S. sanguis, S. oralis, S. intermedius, Streptococcus gordonii, S.mitis and the "green complex" was comprised of Capnocytophaga ochracea, Capnocytophaga gingivalis, Capnocytophaga sputigena, E. corrodens and A. actinomycetemcomitans serotype a. The fifth, "purple complex", consisted of V. parvula and Actinomyces odontolyticus. A. actinomycetemcomitans serotype b, Selenomonas noxia and Actinomyces naeslundii genospecies 2 (A. viscosus) did not fall in any cluster or ordination group.
While species within complexes were closely associated, the complexes themselves had specific relationships with one another. The "red" and "orange complexes" showed a significant association, while the "purple", "yellow" and "green complexes" seemed to be more strongly associated with each other than to either the orange or red complexes. This indicated not only specific relationships between subgingival species, but also suggested a possible pattern or sequence of colonization.

Ximénez-Fyvie, et al. ${ }^{77}$ compared the microbial composition of supra and subgingival plaque in 22 periodontally healthy and 23 adult periodontitis subjects. A total of 2,358 samples of supra and subgingival plaque were collected from up to 28 supra and 28 subgingival sites from both the healthy and the periodontitis subjects, and individually analyzed for their content of 40 bacterial taxa using checkerboard DNA-DNA hybridization. $T$. forsythensis, $P$. gingivalis, $T$. denticola, $P$. intermedia, $P$. nigrescens and $S$. noxia were significantly more prevalent in supragingival plaque samples from periodontitis subjects than periodontally healthy subjects. The distributions for $P$. gingivalis were significantly different between health and disease. The other 2 "red complex" species, T. forsythensis and T. denticola as well as other suspected periodontal pathogens showed similar distributions. Actinomyces species were the dominant taxa in both supra and subgingival plaque from healthy and periodontitis subjects. Both supra and subgingival plaque samples from healthy subjects presented significantly lower total counts than from periodontitis subjects. The main differences found between supra and subgingival plaque, as well as between health and disease, were in the proportions and to some extent levels of Actinomyces, "orange" and "red complexes" species. In another study, Ximénez-Fyvie, et al. ${ }^{78}$ suggested that supragingival plaque may play a role as a reservoir of putative periodontal pathogens. They observed that in a population of adult periodontitis subjects, suspected periodontal pathogens were isolated in supragingival plaque samples from sites where subgingival samples were negative for the same species. However, subgingival plaque samples exhibited significantly higher proportions of "red” and "orange complexes" species in comparison with the supragingival plaque samples.

While our knowledge of the bacterial etiology of periodontal diseases has significantly expanded over the years, many questions still remain unanswered; especially how different kinds of periodontal therapies interfere with this highly organized subgingival population ${ }^{79}$.

\section{MECHANICAL THERAPIES}

The above section suggested some of the likely pathogenic and beneficial species in subgingival plaque. One of the goals of therapy is to control such organisms. The present section examines the effects of periodontal therapies, not including antibiotics, on clinical and microbiological parameters of periodontal diseases. 


\section{Supragingival Plaque Control}

\section{Clinical Studies}

Since the bacterial etiology of periodontal diseases was established, supragingival plaque control has been considered a crucial step in maintaining periodontal health. The classical longitudinal studies carried out in Sweden by Lindhe and co-workers in the 1970s and 80s established the importance of oral hygiene in the success of different types of periodontal therapies. This group of investigators demonstrated that the level of plaque control maintained by the patients after treatment was more critical in preserving the periodontal status and preventing recurrence of destructive periodontitis than the mode of initial therapy used $^{80,81,82,83}$. It is important to emphasize that in most of these studies the patients received professional cleaning after therapy every 2 weeks. Lindhe, et al. ${ }^{80}$ studied the longterm effect of surgical/non-surgical treatment in a group of patients followed for 5 years post-therapy. Patients who during the 5 years of monitoring consistently had a high frequency of plaque-free tooth surfaces showed little evidence of recurrent periodontal disease, while patients who had a low frequency of plaque-free tooth surfaces had a high frequency of sites showing additional loss of attachment. Rosling ${ }^{82}$ and Rosling, et al. ${ }^{83}$ studied the healing potential of periodontal tissues following different forms of periodontal surgery and confirmed that it was possible to treat periodontal disease successfully, even in advanced stages, in patients who were scrupulously maintained by professional cleaning. Similarly, Nyman and co-workers ${ }^{81}$ demonstrated that in plaque-infected dentitions, five different techniques for surgical pocket elimination were equally ineffective in preventing recurrence of destructive periodontitis. Thus, in general, effective supragingival plaque control leads to an improved clinical status for the periodontal patient ${ }^{84}$.

\section{Microbiological Studies}

A limited number of studies have examined the effect of supragingival plaque control on the microbial composition of subgingival plaque. While some studies found no effect, others suggested that careful supragingival plaque control decreased the amount of subgingival plaque and/or the levels of specific subgingival species or morphotypes. Studies using darkfield microscopy suggested that it is possible to reduce the number of spirochetes and motile rods in subgingival plaque by implementing professional supragingival plaque control ${ }^{85,86,87,88}$. Similarly, studies of subgingival plaque samples using cultural techniques indicated that professional cleaning decreased the total counts of some specific periodontal pathogens including A. actinomycetemcomitans, $P$. gingivalis and other black pigmented rods, and spirochetes ${ }^{85,87,88}$. However, other investigations using similar techniques suggested no significant effects of professional supragingival plaque control on the level and/or composition of subgingival plaque $^{89}$. The contradictions among these data may be due to limitations of the microbiological techniques utilized in some of the studies, as well as the limited number of sites and species evaluated. The development of immunological and DNA probes techniques has been extremely helpful in overcoming these problems. Haffajee and co-workers ${ }^{90}$ used DNA probes for 40 different species to study the effect of professional plaque control, carried out once a week for 3 months, on the microbial composition of the subgingival plaque sampled from each tooth. A decrease in the levels of the majority of the 40 species, in particular the members of the "red" and "orange complexes" were obtained and maintained for at least 3 months. The species that were most significantly reduced included putative periodontal pathogens such as A. actinomycetemcomitans, P. gingivalis, T. forsythensis and T. denticola. However, as seen with other forms of mechanical therapy, supragingival plaque control did not significantly affect the prevalence of any of the presumed pathogenic species supra or subgingivally. It was interesting to observe in this study that at least for 3 months after completion of the professional cleaning phase the microbial profiles of both the supra and subgingival plaque samples in the periodontitis subjects were almost identical to those observed in a second group of 23 periodontally healthy subjects. Ximenez-Fyvie, et al. ${ }^{91}$ observed that weekly professional supragingival plaque removal in adult subjects with periodontitis diminished counts of both supraand subgingival species creating microbial profile comparable to that observed in periodontal health. This microbial profile was maintained for a 9-month period. Similarly, Haffajee, et al. ${ }^{84}$ showed clinical and microbiological beneficial effects of supragingival plaque removal in conjunction with different periodontal therapies.

\section{Scaling and Root Planing}

\section{Clinical Studies}

The clinical findings associated with scaling and root planing (SRP) in different forms of periodontal disease have been discussed by the World Workshop of Periodontology ${ }^{92}$. The overall results indicated a clinical benefit from SRP in terms of reducing inflammation and decreasing probing pocket depth and attachment level measurements, especially at deeper sites ${ }^{93,94,95,96}$. Some studies described a loss of clinical attachment at sites with initially shallow pockets ${ }^{97,98}$ probably related to mechanical trauma from instrumentation. A number of studies compared the efficacy of SRP with surgical procedures ${ }^{80,95,96,98,99,100,101}$. In general, surgical therapy produced greater probing depth reduction than non-surgical therapy over the short term. Some of the early differences diminished during long-term follow-up ${ }^{95,96,101}$. In terms of attachment levels, SRP produced less attachment loss at shallow sites than surgical procedures. Deep periodontal pockets $(>6 \mathrm{~mm}$ ) responded equally favorably to both therapies. 


\section{Microbiological Studies}

Few studies have documented the microbiological changes associated with SRP. Studies using darkfield and phase contrast microscopy consistently reported significant reductions in the percentage of motile rods and spirochetes after SRP and a concomitant increase in the percentage of cocci and non-motile microorganisms ${ }^{86,93,94}$. Other studies, employing cultural techniques, indicated a decrease in groups of organisms such as $A$. actinomycetemcomitans, $P$. gingivalis and other black pigmented rods ${ }^{100,102}$. Several of these studies also noted improvement in clinical parameters such as decreased probing depths, stabilization of attachment levels, and decreased bleeding on probing. These were significantly associated with decreased percentages of spirochetes, motile rods, and $P$. gingivalis ${ }^{100}$. Other investigations showed minimal long-term effects of SRP on the subgingival microbiota ${ }^{103}$ especially for species such as A. actinomycetemcomitans ${ }^{103,104}$. As mentioned in the previous section, the development of immunological and molecular approaches has been helpful in studying the oral microbiota related to periodontal treatment, especially species that are difficult to cultivate or are even uncultivable $^{61}$. Using these techniques, many studies confirmed the reduction of P. gingivalis by SRP $60,61,105,106,107$ and also suggested an effect on T. denticol ${ }^{60,61,105,106}$ as well as T. forsythensis ${ }^{61,105,106,107}$.

Haffajee and co-workers ${ }^{55}$, using DNA probes, evaluated more than 4,000 plaque samples from 57 subjects both pre and post-SRP for their content of 40 subgingival species. The results showed that only $P$. gingivalis, $T$. forsythensis and $T$. denticola were significantly decreased. However, none of these species or any of the other test species were undetectable post-therapy. Further, the data suggested that A. actinomycetemcomitans was minimally affected by this form of therapy. In some cases, subgingival eradication of P. gingivalis or A. actinomycetemcomitans may require additional periodontal therapy ${ }^{107,108,109}$.

\section{Periodontal Surgery}

\section{Clinical Studies}

Periodontal surgeries are usually performed for 3 different purposes: regeneration, esthetics and infection control. This section will discuss the use of periodontal surgery in controlling periodontal infection.

Since the beginning of the century, a wide variety of surgical procedures have been described for treating periodontal diseases. Once the infectious nature of periodontitis was established, periodontal surgery was used as a means to gain access to the subgingival plaque and calculus. Therefore, since the 1970s the common types of surgical therapies have included the modified Widman flap, described by Ramfjord in $1974^{110}$ and the apically repositioned flap, described by Friedman in $1962^{111}$. Most of the clinical results associated with this type of treatment have been discussed in the previous sections of this review.
As described before, the early studies carried out by the Swedish group compared different types of surgical procedures $^{83}$. The patients who maintained a high standard of oral hygiene, by receiving professional plaque control every 2 weeks, were able to maintain their periodontal status up to 5 years, irrespective of the type of surgery performed initially. Because SRP was considered the most basic and time tested form of periodontal therapy, a number of studies compared the surgical procedures to SRP in one way or another ${ }^{80,92,95,96,97,98,99,112}$. These studies reported no differences in terms of clinical inflammation following nonsurgical and surgical therapy, either short or long term. However, Serino et al. ${ }^{113}$ compared the clinical effects of modified Widman flap surgery with those of SRP in 64 subjects with advanced periodontal disease and the incidence of recurrent disease during 12 years of maintenance after active therapy. They found that surgical therapy is more effective than SRP in reducing the overall mean probing pocket depth and eliminating deep periodontal pockets. In addition, more SRP-treated subjects exhibited signs of advanced disease progression following active therapy than the surgical-treated subjects.

\section{Microbiological Studies}

There has been limited interest in studying the effects of periodontal surgery on the composition of the subgingival microbiota. Reduction in the proportion of spirochetes and motile rods concomitant with an increase in the proportions of cocci has been observed after subjects were treated using apically repositioned flaps ${ }^{114}$. Rawlinson and co-workers ${ }^{115}$ using cultural techniques examined the effects of modified Widman flap surgery on the subgingival microbiota of residual periodontal pockets. There was a decrease in the numbers of $P$. intermedia and an increase in the overall percentage of $C$. ochracea post-operatively. At 1 year, an increased number of Gram-negative species were detected, including $P$. intermedia.

Mombelli, et al. ${ }^{116}$, using cultural techniques, monitored the levels of subgingival species, for 1 year, in subjects who received apically repositioned flap surgery. They observed a significant decrease in the total anaerobic viable bacterial counts and in the proportion of the Gram-negative anaerobic rods. Furthermore, $P$. gingivalis, Fusobacterium sp., and $C$. rectus were detected significantly less often after treatment. Capnocytophaga and A. odontolyticus, on the other hand, were more frequently isolated after therapy.

Mombelli, et al. ${ }^{117}$, determined the distribution patterns of $P$. gingivalis, $P$. nigrescens and $A$. actinomycetemcomitans in 852 subgingival microbial samples after scaling and root planing and modified Widman flap procedures in sites with persisting pockets greater than $5 \mathrm{~mm}$. P. nigrescens showed a high frequency in a subject and site levels. Persisting $P$. gingivalis was detected in a high percentage of subjects, but in a low proportion of sites. Only 2 subjects were $A$. actinomycetemcomitans positive after treatment. According to Van der Velden, et al. ${ }^{112}$ in smokers, the periodontal surgery was less effective on clinical parameters and on the 
composition of the subgingival microbiota than in nonsmokers. Although Levy et al. ${ }^{118}$ had similar findings in 7 current smokers, the authors suggested that more subjects should be included in further studies in order to confirm the association between cigarette smoking and clinical and microbiologic surgical therapeutic outcomes in subjects with periodontal disease. Tuan, et al. ${ }^{119}$ observed that when periodontal flap surgery was accompanied by osseous recontouring, this procedure reduced periodontal pocket depths and levels of major periodontal pathogens such as $P$. gingivalis and A. actinomycetemcomitans.

Levy and co-workers, ${ }^{118,120}$ using the checkerboard DNADNA hybridization, studied the changes in the composition of subgingival plaque following surgical elimination of periodontal pockets by apically repositioned flap in 18 subjects with chronic periodontitis. Members of the "red complex" (Socransky, et al. ${ }^{62}$ 1998), T. forsythensis, $P$. gingivalis and $T$. denticola, and certain species of the "orange complex" (Socransky, et al. ${ }^{62}$ 1998) such as C. rectus and $C$. gracilis, were reduced after SRP and showed further reductions after the surgical phase. Certain suspected periodontal pathogens, such as $F$. nucleatum ss polymorphum and $P$. nigrescens were less affected by SRP but showed reductions in mean counts after surgery. One of the most interesting aspects of this study was the further improvement of microbiological and clinical parameters at sites that received SRP only after periodontal surgery had been completed at the deeper periodontal pockets. The authors suggested that the reduction in pocket depth by surgical means and the associated decrease in reservoirs of periodontal pathogens may be important in achieving sustained periodontal stability. Thus, periodontal surgery appears to be an important part of the armamentarium to control periodontal infections.

\section{FINAL THOUGHTS}

It took more than a century of research in order to determine the microbial etiology of periodontal diseases. In regarding the early literature, investigators went through several phases alternating different thoughts about the etiology of these diseases, causing a certain delay in the diagnosis, prevention and treatment of periodontitis. Most of these controversies were due to laboratory techniques limitations, such as the impossibility of identifying some important periodontal pathogens using traditional microbiological tests as microscopic and cultural techniques. The failure to find the right causative agents of disease often led to a therapeutic frustration, changing the course of the studies in periodontology. This is probably the reason why we observe certain phases in the periodontal research history where the concept of microbial etiology of periodontal diseases was completely abandoned. New diagnostic techniques, based on immunology and molecular biology knowledge, developed by the end of the 80's allowed a great evolution in the periodontal microbiology field and initiated "the modern search" for the etiological agents of destructive periodontal diseases. These studies indicated that certain microorganisms or groups of microorganisms relate to disease initiation and progression, while other species, considered to be beneficial, are associated with periodontal health. This knowledge was very important and marked a new phase in terms of periodontal research, where it was possible to define microbiological endpoints for therapy. Nowadays it is generally accepted that the treatment of periodontal infections is an ecological problem, where it is necessary to suppress or eliminate pathogens without suppressing host-compatible species. The changes in the subgingival microbiota after mechanical periodontal therapies such as scaling and root planing, supragingival plaque control and periodontal surgery was reviewed in this paper. It is important to emphasize that other forms of periodontal therapies, such as the use of systemically antibiotics as adjunctive to mechanical therapies, are also being systematically studied and will be reviewed in a following paper.

\section{REFERENCES}

1- Hartzell TB. Etiology of pyorrhea alveolaris with a simplified treatment. J Am Dent Assoc 1925;12:1452-67.

2- Kritchevsky B, Seguin P. The pathogenesis and treatment of pyorrhea alveolaris. Dent Cosmos 1918;60:781-4

3- Plaut HC. Studien zur bacteriellen Diagnostik der Diphtherie und der Anginen. Dtsch Med Wochenschr 1894;20:920-3.

4- Socransky SS, Haffajee AD. Evidence of bacterial etiology: a historical perspective. Periodontol 2000 1994;5:7-25.

5- Gottlieb B. Atiologie und Prophylaxe der Zahnkaries. Z Stomatol $1921 ; 129-32$.

6- Haupl K, Lang FJ. Die marginale paradentitis. Ihre Patologie, Atiologie, Klinik, Therapie und Prophylaxe. Berlin: H.Meusser 1927;1-397.

7- Bunting RW. Is pyorrhea a local or constitutional disease? Dent Cosmos 1922;64:731-7.

8- Goldman HM. Periodontal therapy. St.Louis: Mosby; 1968.

9- Gottlieb B. The formation of the periodontal pocket: diffuse atrophy of the alveolar bone. J Am Dent Assoc 1928;15:462-74.

10- Löe H. Periodontal diseases: a brief historical perspective. Periodontol 2000 1993;2:7-12.

11- Gibbons RJ, Berman KS, Knoettner P, Kapsimalis B. Dental caries and alveolar bone loss in gnotobiotic rats infected with capsule forming streptococci of human origin. Arch Oral Biol 1966;11:54960 .

12- Gibbons RJ, Socransky SS. Enhancement of alveolar bone loss in gnotobiotic mice harbouring human gingival bacteria. Arch Oral Biol 1966;11:847-8.

13- Jordan HV, Keyes PH. Aerobic, Gram-positive filamentous bacteria as etiologic agents of experimental periodontal diseases in hamsters. Arch Oral Biol 1964;9:401-14. 
14- Keyes PH, Jordan HV. Periodontal lesions in the Syrian hamsters. III. Findings related to an infectious and transmissible component. Arch Oral Biol 1964;9:377-400.

15- Macdonald JB, Sutton RM, Knoll ML, Madlener EM, Grainger RM. The pathogenic components of an experimental mixed infection. J Infect Dis 1956;98:15-20.

16- Socransky SS, Hubersak C, Propas D. Induction of periodontal destruction in gnotobiotic rats by a human oral strain of Actinomyces naeslundii. Arch Oral Biol 1970;15:993-5.

17- Schei O, Waerhaugh J, Lovdal A, Aron A. Alveolar bone loss as related to oral hygiene and age. J Periodontol 1959;30:7-16.

18- Löe H, Theilade E, Jensen SB. Experimental gingivitis in man. J Periodontol 1965;36:177-87.

19- Löe H, Anerud A, Boysen H, Morrison E. Natural history of periodontal disease in man. Rapid, moderate and no loss of attachmen in Sri Lankan laborers 14 to 46 years of age. J Clin Periodontol 1986;13:431-45.

20- Baelum V, Fejerskov O, Manji F. Periodontal diseases in adult Kenyans. J Clin Periodontol 1988;15:445-52.

21- Listgarten MA. Structure of the microbial flora associated with periodontal health and disease in man. A light and electron microscopic study. J Periodontol 1976;47:1-18.

22- Listgarten MA, Hellden L. Relative distribution of bacteria at clinically healthy and periodontally diseased sites in humans. J Clin Periodontol 1978;5:115-32.

23- Listgarten MA. Electron microscopic observations of the bacterial flora of acute necrotizing ulcerative gingivitis. J Periodontol 1965;328-39.

24- Slots J. The predominant cultivable organisms in juvenile periodontitis. Scand J Dent Res 1976;84:1-10.

25- Haffajee AD, Socransky SS, Ebersole JL, Smith DJ. Clinical, microbiological and imminological features associated with the treatment of active periodontosis lesions. J Clin Periodontol $1984 ; 11: 600-18$

26- Mandell RL, Ebersole JL, Socransky SS. Clinical immunologic and microbiologic features of active disease sites in juvenile periodontitis. J Clin Periodontol 1987;14:534-40.

27- Dogan B, Antinheimo J, Cetiner D, Bodur A, Emingil G, Bundunli $\mathrm{D}$; et al. Subgingival microflora in Turkish patients with periodontitis. J Periodontol 2003;74: 803-14.

28- Slots J, Reynolds HS, Genco RJ. Actinobacillus actinomycetemcomitans in human periodontal disease: a crosssectional microbiological investigation. Infect Immun 1980;29:101320

29- Zambon JJ, Christersson LA, Slots J. Actinobacillus actinomycetemcomitans in human periodontal disease. Prevalence in patient groups and distribution of biotypes and serotypes within families. J Periodontol 1983;54:707-11.

30- Haraszthy VI, Hariharan G, Tinico EM, Cortelli JR, Lally ET, Davis E; et al. Evidence for the role of highly leuotoxic Actinobacillus actinomycetemcomitans in the pathogenesis of localized juvenile and other forms of early-onset periodontitis. J Periodontol 2000;71:912-22.
31- Cortelli JR, Cortelli SC, Pallos D, Jorge AOC. Presença de Actinobacillus actinomycetemcomitans em indivíduos com periodontite agressiva localizada ou generalizada ou periodontite incipiente. RPG Rev Pós Grad 2002;9:103-8.

32- Ebersole JL, Frey DE, Taubman MA, Smith DJ. An ELISA for measuring serum antibodies to Actinobacillus actinomycetemcomitans. J Periodontal Res 1980;15:621-32.

33- Ebersole JL, Taubman MA, Smith DJ, Genco RJ, Frey DE. Human immune responses to oral micro-organisms. I. Association of localized juvenile periodontitis (LJP) with serum antibody responses to Actinobacillus actinomycetemcomitans. Clin Exp Immunol 1982;47:43-52.

34- Albandar JM, DeNardin AM, Adesanya MR, Diehl SR, Winn DM. Associations between serum antibody levels to periodontal pathogens and early-onset periodontitis. J Periodontol 2001;72:1463-9.

35- Hagewald S, Bernimoulin JP, Kottgen E, Kage A. Salivary IgA subclasses and bacteria-reactive IgA in patients with aggressive periodontitis. J Periodontal Res 2002; 37:333-9.

36- Blix IJ, Hars R, Preus HR, Helgeland K Entrance of Actinobacillus actinomycetemcomitans into Hep-2 cells in vitro. J Periodontol 1984;63:723-8.

37- Mandell RL, Tripodi LS, Savitt E, Goodson JM, Socransky SS. The effect of treatment on Actinobacillus actinomycetemcomitans in localized juvenile periodontitis. J Periodontol 1986;57:94-9.

38- Mihara J, Holt SC. Purification and characterization of fibroblastactivating factor isolated from Porphyromonas gingivalis W50. Infect Immun 1993;61:588-95.

39- vanWinkelhoff AJ, vanSteenbergen TJ, deGraaff J. The role of black-pigmented bacteroides in human oral infections. J Clin Periodontol 1988;15:145-55.

40- Wilson M, Meghji S, Barber P, Henderson B. Biological activities of surface-associated material from Porphyromonas gingivalis. Immunol Med Microbiol 1993;6:147-55.

41- Dahlen G, Manji F, Baelum V, Fejerskov O. Putative periodontopathogens in "diseased" and "non-diseased" persons exhibiting poor oral hygiene. J Clin Periodontol 1992;19:35-42.

42- Slots J, Bragd L, Wikstrom M, Dahlen G. The occurrence of Actinobacillus actinomycetemcomitans, Bacteroides gingivalis and Bacteroides intermedius in destructive periodontal disease in adults. J Clin Periodontol 1986;13:570-7.

43- Kasuga Y, Ishihara K, Okuda K. Significance of detection of Porphyromonas gingivalis, Bacteroides forsythus and Treponema denticola in periodontal pockets. Bull Tokyo Dent Coll 2000;41:10917 .

44- Takeuchi Y, Umeda M, Sakamoto M, Benno Y, Huang Y, Ishikawa I. Treponema socranskii, Treponema denticola, and Porphyromonas gingivalis are associated with severity of periodontal tissue destruction. J Periodontol 2001;72:1354-63.

45- Edwardsson S, Bing M, Axtelius B, Lindberg B, Soderfelt B, Attstrom R. The microbiota of periodontal pockets with different depths in therapy-resistant periodontitis. J Clin Periodontol 1999;26:143-52.

46- Kamma JJ, Baehni PC. Five-year maintenance follow-up of earlyonset periodontitis patients. J Clin Periodontol 2003;30:562-72.

47- Holt SC, Ebersole J, Felton J, Brunsvold M, Kornman KS. Implantation of Bacteroides gingivalis in nonhuman primates initiates progression of periodontitis. Science 1988;239:55-7. 
48- Papapanou PN, Sandros J, Lindberg K, Duncan MJ, Niederman R, Nannmark. Porphyromonas gingivalis may multiply and advance within stratified human junctional epithelium in vitro. J Periodontal Res 1994;29:374-5.

49- Sakamoto M, Suzuki M, Umeda M, Ishikawa L, Benno Y Reclassification of Bacteroides forsythus (Tanner et al. 1986) as Tannerella forsythensis corrig., gen. nov., comb. nov. Int J Syst Evol Microbiol 2002;52:841-9.

50- Lai CH, Listgarten MA, Shirakawa M, Slots J. Bacteroides forsythus in adult gingivitis and periodontitis. Oral Microbiol Immunol $1987 ; 2: 152-7$

51- Tan KS, Song KP, Ong G. Bacteroides forsythus prtH genotype in periodontitis patients: occurrence and association with periodontal disease. J Periodontal Res 2001;36:398-403.

52- van Winkelhoff AJ, Loos BG, van der Reijen WA, van der Velden U. Porphyromonas gingivalis, Bacteroides forsythus and other putative periodontal pathogens in subjects with and without periodontal destruction. J Clin Periodontol 2002;29:1023-8.

53- Huang Y, Umeda M, Takeuchi Y, Ishizuka M, Yano-Higuchi K, Ishikawa I. Distribution of Bacteroides forsythus genotypes in a Japanese periodontitis population. Oral Microbiol Immunol 2003;18:208-14.

54- Tsai CY, Wolff LF, Germaine G, Hodges J. A rapid DNA probe tes compared to culture methods for identification of subgingival plaque bacteria. J Clin Periodontol 2003;30:57-62.

55- Haffajee AD, Cugini MA, Dibart S, Smith C, Kent RLJ, Socransky SS. The effect of SRP on the clinical and microbiological parameters of periodontal diseases. J Clin Periodontol 1997;24:324-34.

56- Taubman MA, Haffajee AD, Socransky SS, Smith DJ, Ebersole JL. Longitudinal monitoring of humoral antibody in subjects with destructive periodontal diseases. J Periodontal Res 1992;27:511-21.

57-Riviere GR, Elliot KS, Adams DF; et al. Relative proportions of pathogen-related oral spirochetes (PROS) and Treponema denticola in supragingival and subgingival plaque from patients with periodontitis. J Periodontol 1992;63:131-6.

58- Simonson LG, Goodman CH, Bial JJ, Morton HE. Quantitative relationship of Treponema denticola to severity of periodontal disease. Infect Immun 1988;56:726-8.

59- Paster BJ, Boches SK, Galvin JL, Ericson RE, Lau CN, Levanos $\mathrm{VA}$; et al. Bacterial diversity in human subgingival plaque. J Bacteriol 2001; $12: 3770-83$

60- Simonson LG, Robinson PJ, Pranger RJ, Cohen ME, Morton HE. Treponema denticola and Porphyromonas gingivalis as prognostic markers following periodontal treatment. J Periodontol $1992 ; 63: 270-3$

61- Caposio P, Torta AI, Romano F, Aimetti M, Romagnoli R, Marchiaro G; et al. Molecular approaches to the identification and treatment monitoring of periodontal pathogens. New Microbiol 2003;26:121-4.

62- Socransky SS, Haffajee AD, Cugini MA, Smith C, Kent RL, Jr. Microbial complexes in subgingival plaque. J Clin Periodontol $1998 ; 25: 134-44$

63- Haffajee AD, Socransky SS, Smith C, Dibart S. The use of DNA probes to examine the distribution of subgingival species in subjects with different levels of periodontal destruction. J Clin Periodontol 1992;19:84-91
64- Nonnenmacher C, Mutters R, de Jacoby LF. Microbiological characteristics of subgingival microbiota in adult periodontitis, localized juvenile periodontitis and rapidly progressive periodontitis subjects. Clin Microbiol Infect 2001;7:213-7.

65- Dzink JL, Socransky SS, Haffajee AD. The predominant cultivable microbiota of active and inactive lesions of destructive periodontal diseases. J Clin Periodontol 1988;15:316-23.

66- Rams TE, Feik D, Slots J. Campylobacter rectus in human periodontitis. Oral Microbiol Immunol 1993;8:230-5.

67- Tanner AC, Dzink JL, Ebersole JL, Socransky SS. Wolinella recta, Campylobacter concisus, Bacteroides gracilis, and Eikenella corrodens from periodontal lesions. J Periodontal Res 1987;22:32730

68- Walker CB, Gordon JM, Magnusson I, Clark WB. A role for antibiotics in the treatment of refractory periodontitis. J Periodontol 1993;64:772-81.

69- Lo Bue AM, Nicoletti G, Toscano MA, Rossetti B, Cali G, Condorelli F. Porphyromonas gingivalis prevalence related to other microorganisms in adult refractory periodontitis. New Microbiol 1999;22:209-18.

70- Choi BK, Park SH, Yoo YJ, Choi SH, Chai JK, Cho KS; et al. Detection of major putative periodontopathogens in Korean advanced adult periodontitis patients using a nucleic acid-based approach. J Periodontol 2000;9:1387-94.

71- Mombelli A, Casagni F, Madianos PN. Can presence or absence of periodontal pathogens distinguish between subjects with chronic and aggressive periodontitis? A systematic review. J Clin Periodontol 2002;29 suppl:10-21.

72- Colombo AP, Teles RP, Torres MC, Souto R, Rosalem WJ, Mendes $\mathrm{MC}$; et al. Subgingival microbiota of Brazilian subjects with untreated chronic periodontitis. J Periodontol 2002;73:360-9.

73- Patel M, Coogan M, Galpin JS. Periodontal pathogens in subgingival plaque of HIV-positive subjects with chronic periodontitis. Oral Microbiol Immunol 2003;18:199-201.

74- Socransky SS, Haffajee AD, Dzink JL. Relationship of subgingival microbial complexes to clinical features at the sampled sites. J Clin Periodontol 1988;15:440-4.

75- Roberts FA, Darveau RP. Beneficial bacteria of the periodontium. Periodontol 2000 2002;30:40-50

76- Socransky SS, Haffajee AD, Dzink JL, Hillman JD. Associations between microbial species in subgingival plaque samples. Oral Microbiol Immunol 1988;3:1-7.

77- Ximénez-Fyvie LA, Haffajee AD, Socransky SS. Comparison of the microbiota of supra and subgingival plaque in health and periodontitis. J Clin Periodontol 2000;27:648-57.

78- Ximénez-Fyvie LA, Haffajee AD, Socransky SS. Microbial composition of supra and subgingival plaque in subjects with adult periodontitis. J Clin Periodontol 2000;27:722-32.

79- Petersilka GJ, Ehmke B, Flemming TF. Antimicrobial effects of mechanical debridement. Periodontol 2000 2002;28:56-71.

80- Lindhe J, Westfelt E, Nyman S, Socransky SS, Haffajee AD. Long-term effect of surgical/non-surgical treatment of periodontal disease. J Clin Periodontol 1984;11:448-58.

81- Nyman S, Lindhe J, Rosling B. Periodontal surgery in plaqueinfected dentitions. J Clin Periodontol 1977;4:240-9. 
82- Rosling B. A comparison of various surgical methods for the treatment of periodontal disease. Dtsch Zahnarztl Z 1983;38:83641.

83- Rosling B, Nyman S, Lindhe J. The effect of systematic plaque control on bone regeneration in infrabony pockets. J Clin Periodontol. 1976;3:38-53.

84- Haffajee AD, Arguello EI, Ximenez-Fyvie LA, Socransky SS. Controlling the plaque biofilm. Int Dent J 2003;53 suppl:191-9.

85- McNabb H, Mombelli A, Lang NP. Supragingival cleaning 3 times a week. The microbiological effects in moderately deep pockets. J Clin Periodontol 1992;19:348-56.

86- Muller HP, Hartmann J, Flores-de-Jacoby L. Clinical alterations in relation to the morphological composition of the subgingival microflora following scaling and root planing. J Clin Periodontol 1986;13:825-32.

87- Smulow JB, Turesky SS, Hill RG. The effect of supragingival plaque removal on anaerobic bacteria deep periodontal pockets. J Am Dent Assoc 1983;107:737-42.

88- Moreira AN, Caniggia LF, Ferreira RC, Veronica C, Alonso C, Piovano S. Effect of supragingival plaque control on subgingival microflora and periodontal tissues. Pesqui Odontol Bras 2001;15:11926

89- Kho P, Smales FC, Hardie JM. The effect of supragingival plaque control on the subgingival microflora. J Clin Periodontol 1985;12:676-86.

90- Haffajee AD, Ximenez-Fyvie LA, Som S, Socransky S.S. Effect of supragingival plaque control on supra and subgingival species. J Dent Res 1999;78: abstract.

91- Ximenez-Fyvie LA, Haffajee AD, Som S, Thompson M, Torresyap O, Socransky SS. The effect of repeated professional supragingival plaque removal on the composition of the supra- and subgingival microbiota. J Clin Periodontol 2000;27:637-47.

92- Proceedings of the World Workshop in Periodontics. 1996

93- Lindhe J, Liljenberg B, Adielson B, Borjesson I. Use of metronidazole as a probe in the study of human periodontal disease. J Clin Periodontol 1983;10:100-12.

94- Lindhe J, Liljenberg B, Adielsson B. Effect of long-term tetracycline therapy on human periodontal disease. J Clin Periodontol 1983;10:590-601.

95- Pihlstrom BL, McHugh RB, Oliphant TH, Ortiz-Campos C. Comparison of surgical and nonsurgical treatment of periodontal disease. A review of current studies and additional results after 61/2 years. J Clin Periodontol 1983;10:524-41.

96- Ramfjord SP, Caffesse RG, Morrison EC, Hill RW, Kerry GJ, Appleberry EA; et al. Four modalities of periodontal treatment compared over five years. J Periodontal Res 1987;22:222-32.

97- Becker W, Becker BE, Ochsenbein C, Kerry, GJ, Caffesse R, Morrison EC; et al. A longitudinal study comparing scaling, osseous surgery and modified Widman procedures. Results after 1 year. J Periodontol 1988;59:351-65.

98- Kaldahl WB, Kalkwarf KL, Patil KD, Dyer JK, Bates RE, Jr. Evaluation of four modalities of periodontal therapy. Mean probing depth, probing attachment level and recession changes. J Periodontol 1988;59:783-93.
99- Isidor F, Karring T. Long-term effect of surgical and non-surgical periodontal treatment. A 5-year clinical study. J Periodontal Res $1986 ; 21: 462-72$

100- Pedrazzoli V, Kilian M, Karring T, Kirkegaard E. Effect of surgical and non-surgical periodontal treatment on periodontal status and subgingival microbiota. J Clin Periodontol 1991;18:598-604.

101- Renvert S, Nilveus R, Dahlen G, Slots J, Egelberg J. 5-year follow up of periodontal intraosseous defects treated by root planing or flap surgery. J Clin Periodontol 1990;17:356-63.

102- Ali RW, Lie T, Skaug N. Early effects of periodontal therapy on the detection frequency of four putative periodontal pathogens in adults. J Periodontol 1992;63:540-7.

103- Mombelli A, Gmur R, Gobbi C, Lang NP. Actinobacillus actinomycetemcomitans in adult periodontitis. II. Characterization of isolated strains and effect of mechanical periodontal treatment. J Periodontol 1994;65:827-34.

104- Nieminen A, Siren E, Wolf J, Asikainen S. Prognostic cirteria for the efficiency of non-surgical periodontal therapy in advanced periodontitis. J Clin Periodontol 1995; 22:153-61.

105- Shiloah J, Patters MR, Dean JW, Bland P, Toledo G. The survival rate of Actinobacillus actinomycetemcomitans, Porphyromonas gingivalis, and Bacteroides forsythus following 4 randomized treatment modalities. J Periodontol 1997;68:720-8.

106- Cugini MA, Haffajee AD, Smith C, Kent RL Jr, Socransky SS. The effect of scaling and root planing on the clinical and microbiological parameters of periodontal diseases: 12- month results. J Clin Periodontol 2000;27:30-6.

107- Fujise O, Hamachi T, Inoue K, Miura M, Maeda K. Microbiological markers for prediction and assessment of treatment outcome following non-surgical periodontal therapy. J Periodontol 2002;73:1253-9

108- Slots J. Update on Actinobacillus actinomycetemcomitans and Porphyromonas gingivalis in human periodontal disease. J Int Acad Periodontol 1999;1:121-6.

109- Socransky SS, Haffajee AD, Ximenez-Fyvie LA, Feres M, Mager D. Ecological considerations in the treatment of Actinobacillus actinomycetemcomitans and Porphyromonas gingivalis in periodontal infections. Periodontol 2000 1999;20:341-62.

110- Ramfjord SP, Nissle RR. The modified widman flap. J Periodontol 1974;45:601-7.

111- Friedman N. Mucogingival Surgery: The apically repositioned flap. J Periodontol 1962;33:328-40.

112- Van Der Velden U, Varoufaki A, Hutter JW, Xu L, Timmerman MI, Winkelhoff AJ; et al. Effect of smoking and periodontal treatment on the subgingival microflora. J Clin Periodontol 2003;30:603-10

113- Serino G, Rosling B, Ramberg P, Socransky SS, Lindhe J. Initial outcome and long-term effect of surgical and non-surgical treatment of adavnced periodontal disease. J Clin Periodontol 2001;28:910-6.

114- Rosenberg ES, Evian CI, Listgarten MA. The composition of the subgingival microbiota after periodontal therapy. J Periodontol 1981;52:435-41

115- Rawlinson A, Duerden BI, Goodwin L. Effects of surgical treatment on the microbial flora in residual periodontal pockets. Eur J Prosthodont Restor Dent 1995;3:155-61. 
116- Mombelli A, Nyman S, Bragger U, Wennstrom J, Lang NP. Clinical and microbiological changes associated with an altered subgingival environment induced by periodontal pocket reduction. J Clin Periodontol 1995;22:780-7.

117- Mombelli A, Schmid B, Rutar A, Lang NP. Persistence patterns of Porphyromonas gingivalis, Prevotella intermedia/nigrescens, and Actinobacillus actinomycetemcomitans after mechanical therapy of periodontal disease. J Periodontol 2000;71:14-21.

118- Levy RM, Gainnobile WV, Feres M, Haffajee AD, Smith C, Socransky SS. The effect of apically repositioned flap surgery on clinical parameters and the composition of the subgingival microbiota: 12-month data. Int J Periodontics Restorative Dent 2002; 22:20919

119- Tuan MC, Nowzari H, Slots J. Clinical and microbiological study of periodontal surgery by means of apically positioned flaps with and without osseous recontouring. Int J Periodontics Restorative Dent 2000;20:468-75.

120- Levy RM, Giannobile W, Feres M, Haffajee AD, Socransky SS The short-term effect of apically repositioned flap surgery on the composition of the subgingival microbiota. Int J Period Rest Dent 1999;19:555-67. 